\title{
Rebound effects in persuasion: considering potential ironic effects of suppression and correction / Efectos rebote en la persuasión: una consideración de los posibles efectos irónicos de la supresión y la corrección / Efectos rebote en la persuasión: una consideración de los posibles efectos irónicos de la supresión y la corrección
}

\author{
Pedro P. Silva ${ }^{\mathrm{a}}$, Teresa Garcia-Marques $\overbrace{}^{\mathrm{a}}$, and Duane T. Wegener $\oplus^{\mathrm{b}}$ \\ ${ }^{a}$ ISPA, Instituto Universitário; ${ }^{b}$ Ohio State University \\ (Received 24 February 2019; accepted 26 July 2019)
}

\begin{abstract}
Previous theory and research in persuasion has failed to examine possible ironic effects of attempting to suppress or to correct for influences of a potentially biasing source. Yet, because people often encounter sets of persuasive communications in order (e.g., in advertising), such rebound effects seem possible. Data on such possibilities are scarce, however. Here we present a relevant study. It followed the typical single-shot persuasive message with a second message on an unrelated topic but employed a similar type of (potentially biasing - attractive or unattractive) source. Attitudes following the second communication showed increased source impact for participants asked to suppress source-related thoughts during the first message (especially when the second message was encountered under load). Instructions to correct for potential source effects during the first message did not show ironic effects following the second message. This relatively small study is not enough to make definitive claims, but it suggests that rebound effects of thought suppression are possible in (repeated) persuasion settings. Future research and open questions regarding ironic effects are discussed.
\end{abstract}

Keywords: persuasion; bias control; suppression; correction; ironic effects; rebound effect

Resumen: Ni la teoría ni las investigaciones previas sobre la persuasión han estudiado los posibles efectos irónicos de los esfuerzos por suprimir o corregir la influencia de una posible fuente de sesgos. Sin embargo, puesto que las personas suelen recibir mensajes persuasivos de manera ordenada (e.g., en la publicidad), dichos efectos irónicos posiblemente existan, si bien los datos sobre este fenómeno son escasos. En este artículo se presenta un estudio sobre este tema.

English version: pp. 1-12 / Versión en español: pp. 13-23

References / Referencias: pp. 24-27

Translated from English / Traducción del inglés: Mercè Rius

Authors' Address / Correspondencia con los autores: Teresa Garcia-Marques, Departamento de Psicologia Social e Organizacional, ISPA- Instituto Universitário, Rua Jardim do Tabaco, 34, Lisboa 1149-041, Portugal. E-mail: gmarques@ispa.pt 
En el estudio se utilizó el típico mensaje persuasivo único de efecto inmediato con un segundo mensaje sobre un tema no relacionado pero se introdujo un tipo de fuente similar (como causa potencial de sesgo - atractiva o no atractiva). Las actitudes expresadas tras la segunda comunicación revelaron mayor impacto de la fuente en los participantes que tenían que suprimir pensamientos relacionados con la fuente durante el primer mensaje (especialmente cuando el segundo mensaje era recibido en condiciones de carga alta). La orden de corregir posibles efectos de la fuente durante el primer mensaje no reveló efectos irónicos tras el segundo mensaje. El tamaño relativamente reducido de este estudio no permite extraer conclusiones definitivas, pero sugiere la posibilidad de que la supresión de pensamientos origine un efecto rebote en contextos persuasivos. Se plantean posibles investigaciones futuras y preguntas abiertas sobre los efectos irónicos.

Palabras clave: persuasión; control de sesgos; supresión; corrección; efectos irónicos; efecto rebote

Persuasion research has traditionally addressed isolated persuasive messages (see Albarracín, Johnson, \& Zanna, 2005; Petty \& Wegener, 1998, for reviews). However, many everyday persuasive situations include two or more (unrelated) messages in close succession. For example, most commercial breaks on television consist of a series of ads for different products endorsed by different people. Recognizing this, Tormala and Clarkson $(2007,2008)$ showed that perceived credibility of the source of a target message can be directly influenced by perceptions of the credibility of the source of another message that was previously encountered in that context (promoting either assimilation or contrast depending on other variables; for a general discussion of such context effects, see Chien, Wegener, Hsiao, \& Petty, 2010). Indirect effects of such context messages can also be expected. For example, research on depletion of self-regulatory resources suggests that activities surrounding a target persuasive message can deplete individual resources, making it harder to resist counterattitudinal target messages (Burkley, 2008; Wheeler, Briñol, \& Hermann, 2007). Because persuasion is often characterized by the impact of several context features, protection against such influences may occur through the triggering of general resistance processes in addition to processes directed at specific bias regulation (see Wegener, Petty, Smoak, \& Fabrigar, 2004). In this paper we discuss potential outcomes of bias regulation strategies. In particular, we examine the potential for bias control attempts to paradoxically promote or increase the later impact of the variables whose influence was to be avoided (an ironic effect) compared with the later impact of the variables when no previous bias control attempts had occurred. To address such ironic effects, we consider consequences for a second persuasive message. In particular, we focus on how attempts to control bias on an initial message might influence reactions when later confronted with a persuasive message that could potentially produce a similar bias.

To date, in the persuasion literature, explicit attempts to avoid biases from contextual features, such as source characteristics, have focused on corrective processes themselves (e.g., Chien \& Hsiao, 2015; Kang \& Herr, 2006; Petty, Wegener, \& White, 1998). That is, when one becomes aware of a potential bias, such as agreement with an attractive source (e.g., Chaiken, 1979), the message 
recipient might try to eliminate that bias by adjusting thoughts or other responses to the message based on the perceived direction and magnitude of the source-based bias (see Chien, Wegener, Petty, \& Hsiao, 2014; Wegener \& Petty, 1997). Prior research has generally shown that these correction processes are more likely to occur when the amount of thinking is relatively high (e.g., Chien \& Hsiao, 2015; Johar \& Simmons, 2000). This is because in order to calibrate judgments, people need to have enough motivation and ability to think about their own thought processes (Wegener \& Petty, 1997; Wilson \& Brekke, 1994).

It seems possible that ironic effects could sometimes result from attempts to correct a bias. As suggested by Strack and Mussweiler (2001; see also Wegener, Silva, Petty, \& Garcia-Marques, 2012), accessing naive theories of bias and considering the necessary adjustments may inadvertently prime the biasing variable or concept itself. If so, subsequent ironic effects of increased bias might be promoted through its increased accessibility (cf. Macrae, Bodenhausen, Milne, \& Jetten, 1994) ${ }^{1}$. If so, then it seems plausible that consideration of a bias when trying to avoid that bias could increase the accessibility of the biasing factor beyond the setting in which correction goals were first activated (in contrast, if the bias-correction goal itself is adequately served in the initial persuasion setting, that goal to correct could often be short-lived and mostly confined to that initial setting; cf. Förster, Liberman, \& Friedman, 2007). On the other hand, if the person believes that the goal of avoiding that bias continues to be relevant beyond the initial persuasion setting, it could be that accessibility of the correction goal would persist, potentially leading to continued reductions in the bias (or even overcorrection) rather than ironically increased influences of the bias.

However, awareness of a potential bias might also sometimes motivate different types of approaches to bias reduction, such as attempts to suppress thoughts reflecting the bias (i.e., keeping 'biased thoughts' out of consciousness). Consequences of initial suppression for later thinking have been widely studied outside of persuasion. Suppression is frequently associated with ironic delayed effects wherein the unwanted thoughts rebound and have increased impact in a later setting (Wegner, Schneider, Carter, \& White, 1987; see Wenzlaff \& Wegner, 2000 for a review; Abramowitz, Tolin, \& Street, 2001 for a meta-analysis). For example, after successful stereotype suppression, social perceivers later show more stereotype-consistent responses when they encounter a target towards which the stereotypical reactions might apply (Macrae et al., 1994). This subsequent impact of the suppressed construct is usually attributed to its hyper-accessibility (a consequence of the monitoring processes underlying suppression; Wegner, 1994; see Giuliano \& Wicha, 2010 for electrophysiological evidence) when there is no longer motivation (Macrae et al., 1994) or cognitive resources (Wyer, Sherman, \& Stroessner, 2000) to continue suppressing (cf., Förster \& Liberman, 2004; Gordijn, Hindriks, Koomen, Dijksterhuis, \& van Knippenberg, 2004). It could be that similar rebound effects might occur when people attempt to control bias in contexts of sequential persuasive settings. In particular, suppressing a variable (such as source attractiveness) in one persuasive situation might increase the impact of that variable in a subsequent unrelated persuasive situation. 
Data addressing such possibilities are few and far between. Perhaps as a result, few discussions of potential ironic effects in persuasion have appeared (for an exception, see Wegener et al., 2012). In the current article, in addition to discussing this interesting possibility, we also describe one of the few studies (see Silva, 2012) that aimed to compare bias correction and suppression strategies for bias control in order to directly compare their consequences (see Yzerbyt, Corneille, Dumont, \& Hahn, 2001 for a related comparison in control of dispositional inferences in impression formation). The study presented here was the first to compare suppression and correction control strategies in persuasion. That is, it tested delayed effects of bias control attempts by giving participants two ostensibly unrelated persuasive messages (on different issues, with different sources, presented by different experimenters). Each message was accompanied by an attractive or unattractive source. Participants were either given bias-control instructions (promoting either suppression or correction) before receiving the first persuasive message or were not. For participants prompted to control bias, in order to promote efficient activation and use of the bias-control strategies for that message, participants were not deprived of motivational or cognitive resources (cf. Wyer, 2007; Wyer et al., 2000).

No bias-control instructions were given for the second persuasive message. However, cognitive load was manipulated during receipt of the second message. This was done for two reasons. First, as Wyer et al. (2000) showed in stereotype suppression, cognitive load enhances the likelihood of the accessible mental contents being applied to the later target even if participants are motivated to avoid the bias. Second, cognitive load during the second message provides favourable conditions for detecting the impact of potential peripheral cues such as source attractiveness on attitudes (similar to single-message situations, see Chaiken, Liberman, \& Eagly, 1989; Petty \& Cacioppo, 1986).

The idea is that controlling perceived influences of a source characteristic during a first message can increase its salience or accessibility (compared to the control group) when a second message was encountered. If so, then ironic effects of attempts to control bias would be evident in source attractiveness effects being greater following attempts to suppress or to correct than they are in control conditions. This pattern could appear as an Instruction X Source interaction if appearing across levels of cognitive load experienced during the second message or as an Instruction $\times$ Source $\times$ Load interaction if the ironic effects occur more when under high cognitive load during the second message.

In addition, the design also allowed for the detection of immediate ironic effects (i.e., at the initial persuasive situation), which has also been identified in suppression research (see Wenzlaff \& Wegner, 2000; and further discussion by Silva, 2012). Such effects could also constitute an ironic consequence of bias control processes not yet considered in the persuasion literature. Below we summarize the methods and data of this experiment. 


\section{Method}

\section{Participants and design}

The sample consisted of 136 undergraduates (110 females) who were randomly assigned to a 3 (instruction: suppression vs. correction vs. control) $\times 2$ (source: attractive vs. unattractive $) \times 2$ (cognitive load during second message: low vs. high) between-subject design.

\section{Procedure}

Participants engaged in two pretests (each supposedly managed by a different student) presented on a computer screen that represented two thematically unrelated persuasive situations. Pretest 1 was introduced as an advertising study. All participants saw a draft of an advertisement for a USB storagedevice characterized by the product image, its name and the message 'With the NewTek3000 I can store and transfer data regularly! It's a practical, fast and safe solution!' The draft ad also included indications of where four product details/ characteristics would be placed in the final version. However, these were not specified in the version under evaluation and were represented by displaying labels like 'Characteristic W'. All participants were informed that several features were being pretested before deciding on the ad's final format, and that they should focus on the presented message. Importantly, the ad included a photograph of a young man we had previously pretested to be either relatively physically attractive or unattractive ${ }^{2}$.

The correction and suppression conditions added to these general instructions. Both correction and suppression conditions called attention to the fact that 'One of the aspects we are still deciding on is the photo shown in the ad. However, we decided to put one in the respective location to convey a general sense of what the final ad will look like'. Correction instructions then asked participants to remember that the photo was not the final one and to "'adjust" your evaluations of the message' accordingly. The suppression condition directed participants to "ignore the person presented in the ad by "forgetting" it when you are evaluating the message'.

All participants then provided product evaluations (very bad/very good, totally useless/totally useful and not interesting/very interesting), willingness to buy the product (surely not/for sure) and message evaluations (very bad/very good, not effective/very effective) on nine-point scales (from 1 to 9 , as all other ratings reported). These responses were highly correlated (Cronbach $\alpha=.846$ ) and were averaged to create a composite measure of participants' first phase evaluations (from here referred to as post-message1 attitudes).

Then, participants were thanked and asked to press a key to initiate their subsequent participation in the next study. A loading screen appeared for eight seconds followed by a welcome screen introducing Pretest 2 with a completely different format addressing environmental psychology. A pamphlet advocating for municipal bicycle systems was being developed to be distributed with 
a request to sign a petition. Participants were additionally informed that to simulate the busy environment where people would read the pamphlet, they should memorize a number and report it accurately at the end of the study. Either a two-digit (low-load) or seven-digit (high-load) number was presented for 10 seconds. The pamphlet included a personal communication attributed to a young man pictured on-screen whose physical appearance had been pre-tested as relatively attractive or unattractive. Though different attractive or unattractive images were associated with the second message than with the first message, the attractiveness levels were matched across messages. There were no bias-control instructions provided with the second message (i.e., Pretest 2). The communication content was: 'I lived in the Netherlands for 2 years and I always moved by bicycle. Besides being a non-polluting way of transportation, it's a great way of getting regular exercise. One of the main problems I have here is where to leave it. If city councils were to have municipal bicycles and places to pick up and return them, everything would be easier!'

Attitudes towards the issue (i.e., completely agree/completely disagree; not at all interesting/very interesting) and towards the message (i.e., not at all effective/very effective; not at all convincing/very convincing; not at all adequate/very adequate; not at all persuasive/very persuasive; very bad/very good; not at all/very motivating for others to sign a petition, and not at all very motivating for themselves to sign a petition) were assessed on nine-point scales. These responses were highly correlated and were averaged into a composite measure (Cronbach $\alpha=$.914) referred to as participants' postmessage 2 attitude. Then, participants reported the memorized number and also, using nine-point scales, their general task motivation (don't like it/like it and not interesting/very interesting; $r=.83$ ), and source attractiveness for the two photos they had seen (very ugly/very beautiful; not attractive/very attractive; Pretest 1 source attractiveness ratings: $r=.89$; Pretest 2 source attractiveness ratings: $r=.90)$.

\section{Results}

Preliminary analysis of the post-message 1 attitudes resulted in identification of three outliers that were removed from further analysis. Preliminary analysis of the post-message 2 attitudes resulted in identification of five outliers that were removed from further analysis alongside two participants who did not comply with the cognitive load task performance (see below) ${ }^{3}$. Also, at the end of the two tasks, participants across all conditions reported relatively high task motivation $(M=7.37, S D=1.35)$. Such responses suggest willingness on the part of participants to pay close attention to the activities in the study (including, perhaps, relatively high levels of issue-related elaboration). 


\section{Manipulation checks}

As intended, sources for both messages differed in perceived level of attractiveness. A 3 (Instruction) $\times 2$ (Source attractiveness) $\times 2$ (Load) Analysis of Variance (ANOVA) showed that for Pretest 1 (the first message), the attractive source $(M=4.88)$ was viewed as more attractive than the unattractive source $(M=2.69), F(1,124)=71.50, p<.001, \mathrm{y}^{2}=.366$. No other effect was found (all $F \mathrm{~s}<1$ ). Also in Pretest 2 (the second message), the attractive source was viewed as more attractive $(M=4.85)$ than the unattractive source $(M=2.39), F(1,124)=127.90, p<.001 \mathrm{y}^{2}=.508$. This strong Source impact on attractiveness ratings was qualified by Instructions [Instruction $\times$ Source, $F(2,124)=5.39, p=.006, \mathrm{y}^{2}=.080$ ] and by Load [Source $\times$ Load, $\left.F(1,124)=6.82, p=.010, \mathrm{y}^{2}=.052\right]$. Participants in the correction condition rated the source more similarly across levels of manipulated attractiveness $\left(M_{\text {attractive }}=4.03 ; M_{\text {unattractive }}=2.59\right)$ than those in the suppression conditions $\left(M_{\text {attractive }}=5.29 ; M_{\text {unattractive }}=2.28\right)$ or control conditions $\left(M_{\text {attractive }}\right.$ $=5.23 ; M_{\text {unattractive }}=2.29$ ). However, and importantly, when directly comparing the attractive and unattractive sources within the correction condition, the ratings revealed a relatively strong and significant manipulation, $t$ $(124)=3.72, p<.001 ; d=0.67$.

Likewise, although high-load participants rated sources more similarly $\left(M_{\text {attractive }}=4.54 ; M_{\text {unattractive }}=2.65\right)$ than low-load participants $\left(M_{\text {attractive }}\right.$ $=5.16 ; M_{\text {unattractive }}=2.13$ ), comparing the attractive and unattractive sources showed that the manipulation was effective even in the high-load condition, $t$ $(124)=6.15, p<.001 ; d=1.10$. The three-way interaction between levels of instruction, source attractiveness and cognitive load was not significant $(F<1)$.

\section{Pretest 1: the initial persuasive message}

On the first persuasive message, suppression might either remove any source effect or, if not effective, could ironically promote or enhance its effect over participants' attitudes. As in past research, correction instructions should work to decrease any impact of source attractiveness, either diminishing attractiveness effects or reversing attractiveness effects due to overcorrection (see Kang \& Herr, 2006; Petty et al., 1998).

Suggesting potential effectiveness of correction instructions and paradoxical effects of suppression, the Instruction $\times$ Source ANOVA (factors manipulated before these post-message 1 attitudes were measured) revealed only a significant interaction, $F(2,127)=4.18, p=.017, \mathrm{y}^{2}=.062$. In order to understand this interaction, we conducted planned contrasts comparing post-message 1 attitudes across source conditions within each instruction type. Post-message1 attitudes were more favourable with an attractive $(M=5.91)$ rather than unattractive $(M=4.87)$ source only under suppression conditions, $t(127)=2.71, p=.008, d=0.48$. No significant attractiveness effects were present for the control $\left(M_{\text {attractive }}=5.60 ; M_{\text {unattractive }}=6.14\right)$ or correction conditions $\left(M_{\text {attractive }}=5.83 ; M_{\text {unattractive }}=5.76\right), t \mathrm{~s}<1.36$. 


\section{Pretest 2: second persuasive message}

Suggesting the compliance of participants with the cognitive load manipulation, all participants in the low-load condition reported the number correctly. Two participants in the high-load condition who recalled fewer than half of the seven digits correctly were removed from subsequent analysis (see Gilbert \& Hixon, 1991).

Post-message 2 attitudes were analysed using a 3 (instruction) $\times 2$ (source) $\times 2$ (cognitive load) ANOVA. This analysis revealed a marginal Instruction $\times$ Source interaction, $F(2,117)=2.72, p=.070, \mathrm{y}^{2}=.045$, that mirrored the effects obtained following the first persuasive message, at least in some respects. Paired comparisons between the two source conditions showed that although attractiveness did not exert significant impact in the control condition ( $M_{\text {attractive }}$ $\left.=6.57 ; M_{\text {unattractive }}=6.63 ; t<1\right)$, its 'ironic' influence was seen in the suppression condition $\left(M_{\text {attractive }}=6.53 ; M_{\text {unattractive }}=5.79 ; t(117)=2.01\right.$ $p=.047 ; d=0.37)$. There was also no significant effect of source attractiveness in the correction condition $\left(M_{\text {attractive }}=5.77 ; M_{\text {unattractive }}=6.29 ; t(117)=1.26\right.$, $p=.211 ; d=0.23)$. Indeed, if anything, there might have been some carry-over in corrective goals per se in that the unattractive source led to non-significantly more favourable reactions to the message than the attractive source (see Table 1).

The omnibus three-way interaction among Instructions, Source and Load did not achieve standard levels of significance, $F(2,117)=2.161, p=.120, \mathrm{y}^{2}=.036$. However, when analysis focuses only on the comparison between the suppression and control conditions, a 2 (Instructions) $\times 2$ (Source) $\times 2$ (Load) ANOVA revealed the potential ironic effects of suppressed source attractiveness to be moderated by load Instruction $\times$ Source $\times$ Load interaction, $F(1,117)=4.28, p=.041, \mathrm{y}^{2}=.041$. When participants were under high-load conditions during the second message, the simple Instruction $\times$ Source interaction revealed that effects of source attractiveness were significantly greater when participants had been asked to suppress source attractiveness during the first message $\left(M_{\text {attractive }}=6.82 ; M_{\text {unattractive }}=5.48\right)$ than when they had not (i.e., in control conditions; $\left.M_{\text {attractive }}=6.21 ; M_{\text {unattractive }}=6.77\right), t(117)=2.59$, $p=.011, d=0.49$. Moreover, the comparison of attractive versus unattractive source conditions for the second message was significant when participants had been asked to suppress during the first message, $t(117)=2.61, p=.010, d=0.48$, but not when

Table 1. Message 2 mean attitude evaluations (standard deviations in parentheses).

\begin{tabular}{|c|c|c|c|c|}
\hline & \multicolumn{4}{|c|}{ Cognitive Load } \\
\hline & \multicolumn{2}{|c|}{ Low } & \multicolumn{2}{|c|}{ High } \\
\hline & \multicolumn{2}{|c|}{ Source } & \multicolumn{2}{|c|}{ Source } \\
\hline Instructions & Attractive & Unattractive & Attractive & Unattractive \\
\hline Control & $6.93(0.81)$ & $6.49(0.99)$ & $6.21(1.10)$ & $6.77(0.61)$ \\
\hline Correction & $6.19(1.75)$ & $6.69(1.40)$ & $5.36(1.41)$ & $5.89(0.71)$ \\
\hline Suppression & $6.23(1.70)$ & $6.10(1.41)$ & $6.82(0.70)$ & $5.48(1.51)$ \\
\hline
\end{tabular}


encountering the first message with no alerting to any potential bias (i.e., control conditions), $t(117)=1.06, p=.291 . d=0.195$. However, there was a different pattern when participants were under low load during the second message. That is, attitudes were not affected by attractiveness of the source of the second message when they had been asked to suppress during the first message $\left(M_{\text {attractive }}=6.23 ; M_{\text {unattractive }}=6.10\right.$; $t<1)$ or in control conditions $\left(M_{\text {attractive }}=6.93 ; M_{\text {unattractive }}=6.49 ; t<1\right), F<1$ for Instruction $\times$ Source.

Regarding the comparison of the impact of Source attractiveness for the second message when participants had been asked to correct on the first message (compared with control conditions), there were no significant differences between correction and control conditions overall $(F<1)$, nor was this relation affected by load (three-way interaction: $F<1$; see Figure 1).

\section{Power considerations}

Here we add to Silva (2012)'s considerations of likely power for the reported analysis. The study was conducted at a time when power received less attention in the literature, but with only a single study, clearly any conclusions from the study should be tempered by the potential for the body of low-power singlestudy publications to include a higher proportion of Type I errors (Pashler \& Harris, 2012). This may be especially true given the somewhat speculative nature of any comparisons between potential ironic effects of suppression versus correction per se. As additional tests of potential ironic effects are conducted, the level of power for any one study might matter less than the potential for the larger set of data to identify such effects (for additional discussion, see Fabrigar \& Wegener, 2016; McShane \& Böckenholt, 2017). As a first study on this topic, one could perhaps use the relevant effects (such as the observed three-way interaction among Instruction, Source and Load when comparing only initial suppression and control conditions) as an estimated effect size for future studies $\left(f^{2}=0.193\right)$. If one were to do that, it would take approximately 262 participants to reach $80 \%$ power across replications. It is entirely possible, however, that any

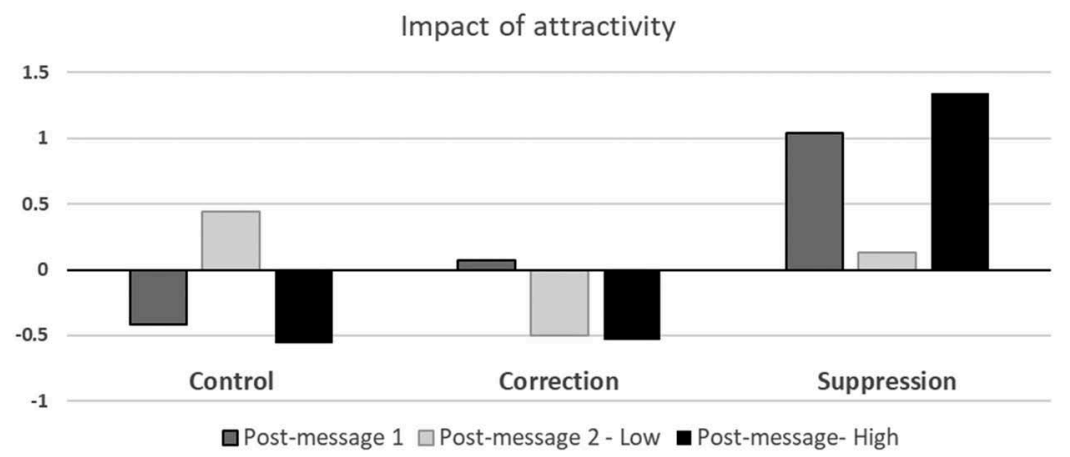

Figure 1. Differential impact of source attractiveness (attractive — unattractive) in each experimental condition. 
estimate taken from this single study might represent an over-estimate of the effect in the population. If so, then efforts to examine similar ironic effects might ultimately require considerably more participants than estimated on the basis of the current results.

\section{Discussion}

This study (from Silva's, 2012 thesis) focused on the consequences of bias control strategies activated in one persuasive situation for a subsequent message. To our knowledge, this was the first study that directly addressed potential rebound effects in persuasion. As a preliminary study (and given power restrictions), any conclusions must be taken with caution, but some parts of the study do suggest that ironic effects of suppression are possible in persuasive contexts. More specifically, the study suggests that initial attempts to suppress thoughts consistent with source characteristics might ironically increase source effects in a subsequent message compared with a control condition in which initial sourcerelated thoughts were not suppressed. Despite the preliminary nature of the current data, we thought it potentially useful to present the study here in hopes it might prompt new attempts to examine ironic influences of bias-control strategies in persuasion.

\section{Limitations and explanations}

In the current study, ironic effects of suppression of source attractiveness effects occurred particularly when participants possessed few cognitive resources when receiving the second message (i.e., under high cognitive load conditions). High levels of load during the second message could set the stage for the strongest effects of accessible source attractiveness. Yet, on some level the pattern remains curious in that source effects on the second message should have also been more likely under high- than low-load conditions even in the control group (but this did not occur). It is possible that there was a general lack of attention to source attractiveness that was only enhanced when instructions to suppress during the first message made the source feature more accessible.

Regarding attempts at bias correction (i.e., adjusting for perceived influence), however, the current study did not reveal delayed ironic effects (see also Yzerbyt et al., 2001). Yet, it may still be worth exploring that possibility in future research. For example, the current study examined suppression and correction in a relatively information-sparse setting (i.e., with little information to elaborate). In more information-rich settings, however, more extensive and effortful instances of correction might produce rebound effects because of repeated consideration of the biasing factor or because of depletion of self-regulatory resources. In contrast, for suppression, information-rich contexts may provide additional diversity of distracter mental contents (unrelated to a subsequent context), thereby indirectly making it easier to keep undesired content (e.g., source attractiveness) out of consciousness, and reducing later ironic effects 
(see Silva, 2012; Wegener et al., 2012, for more discussion, including the role of other aspects such as the timing of bias-control instructions).

Any ironic effects of suppression in the current study would not have merely resulted from drawing attention to source attractiveness and its biasing effects because correction instructions did not have the same effects. Rather, there might be something crucial about trying to put the source characteristic 'out of one's mind' (possibly related to individuals' lack of awareness of repeatedly thinking about the source of the message; cf. Baird, Smallwood, Fishman, Mrazek, \& Schooler, 2013). Typical mechanisms triggered by suppression include increased accessibility (Wegner, 1994), self-regulatory depletion (Gailliot et al., 2007) or motivational inferences (Förster \& Liberman, 2004). However, another explanation is that ironic effects of suppression result from procedural priming, where attention to the topic of the suppressed thought continues across settings (cf. Shen \& Wyer, 2008). Some form of procedural priming might also be relevant to why bias correction on a first message led to tendencies to also correct on a subsequent message. That is, those in the correction and suppression conditions might have kept using (or attempting to use) those strategies when they encountered the second persuasive message. In the current work, however, we have to note that a key limiting factor on both the suppression and correction sides is that little evidence demonstrated that participants were specifically suppressing or correcting during the first message, let alone which mechanisms might be at work when suppressing or correcting. The differences in outcomes across instruction conditions suggested that participants were doing something different across conditions, but we have no guarantee that they adhered closely to the intended processes or which potential mechanisms might be at work.

In conclusion, in line with Tormala and Clarkson $(2007,2008)$ and Chien and Hsiao (2015), we would stress the need for persuasion research to look beyond the single-shot persuasive message contexts that have dominated the research literature (see also Cialdini \& Guadagno, 2004; Sleeth-Keppler \& Wheeler, 2011). Though we acknowledge the possibility of immediate ironic effects, our main interest here is in downstream effects that attempts to control potential biases can have on how people deal with a later conceptually unrelated message.

This dynamic and temporal broadening of perspective seems particularly important considering that people regularly encounter a succession of persuasive messages about different topics (often presented by different sources). In some of these settings, content encountered prior to the persuasive messages might prompt attempts at bias regulation (as when attractiveness is viewed as a reason for undue success of a communicator encountered prior to the persuasive appeal, e.g., Kang \& Herr, 2006; or early appeals exhort people to ignore celebrity endorsers of other brands, as in the 'Obey Your Thirst' ads for Sprite; Chien \& Hsiao, 2015). The persuasion domain in general, and dynamic multiplemessage settings in particular, can also provide good contexts in which to examine distinctions between different strategies for attempting bias control (such as correction and suppression). These have been scarcely compared, and many interesting questions (and potentially meaningful consequences) remain. 


\section{Notes}

1. Previous rebound effects have generally been empirically associated with attempts to suppress particular kinds of thoughts rather than with attempts to avoid a particular bias. To examine ironic (rebound) effects of correction would require specific experimental designs not previously used in research focusing on corrective processes. For example, in a persuasion context, detecting a rebound effect of correcting for source likability (e.g., Petty et al., 1998) would require a subsequent persuasive situation where that variable (source likability) can have a detectable effect. Sequential message studies are infrequent, and no previous studies were designed to examine rebound effects of bias correction.

2. Both attractive and unattractive faces for Pretest 1 and 2 used images from Minear and Park (2004) and Tottenham et al. (2009). However, for the attractive versions several images were used to create average morphed final faces, in order to achieve higher attractiveness.

3. These outliers were simply identified using boxplot in SPSS (1.5IQR), separately for each cell in the design. Notice that the currently described analysis removed different outliers from responses to the first persuasive message and to the second persuasive message. The interdependence of both phases might recommend complete removal of outlying participants from all analyses. That strategy does not change the reported pattern of results. 


\section{Efectos rebote en la persuasión: una consideración de los posibles efectos irónicos de la supresión y la corrección}

Tradicionalmente, el estudio de la persuasión se ha centrado en mensajes persuasivos aislados (véase Albarracín, Johnson, \& Zanna, 2005; Petty \& Wegener, 1998). Sin embargo, muchas situaciones persuasivas cotidianas incluyen dos mensajes sucesivos o más (no relacionados entre sí). Por ejemplo, la mayoría de las pausas comerciales televisivas consisten en una serie de anuncios de distintos productos presentados por distintas personas. En vista de ello, Tormala y Clarkson $(2007,2008)$ demostraron que la credibilidad percibida de la fuente de un mensaje meta podría estar influida directamente por las percepciones de la credibilidad de la fuente de un mensaje previo en ese mismo contexto (que fomenta la asimilación o el contraste, en función de otras variables; para una discusión general de estos efectos del contexto, véase Chien, Wegener, Hsiao, \& Petty, 2010). También pueden esperarse efectos indirectos de este tipo de mensajes contextuales. Por ejemplo, las investigaciones sobre el agotamiento de los recursos de autocontrol sugieren que las actividades que rodean a un mensaje persuasivo pueden agotar los recursos individuales, lo que dificulta que la persona resista los mensajes contra-actitudinales (Burkley, 2008; Wheeler, Briñol, \& Hermann, 2007). Dado que la persuasión se suele caracterizar en función del impacto de diversos aspectos contextuales, puede producirse una protección frente a dichas influencias mediante la activación de diversos procesos de resistencia generales, además de los procesos dirigidos al control específico del sesgo (véase Wegener, Petty, Smoak, \& Fabrigar, 2004). En este artículo se discuten los posibles resultados de las estrategias de regulación del sesgo. Analizamos, en particular, la posibilidad de que los intentos de controlar el sesgo fomenten o aumenten paradójicamente el impacto último de las variables cuya influencia se quería evitar (efecto irónico) en comparación con el efecto último de las variables cuando no se realiza un intento anterior de controlar el sesgo. Para estudiar dichos efectos irónicos tenemos en cuenta sus consecuencias en un segundo mensaje persuasivo. En concreto, nos centramos en cómo influirían los intentos de controlar el sesgo en un mensaje inicial cuando la persona se enfrenta después a un segundo mensaje persuasivo que podría producir un sesgo similar.

Hasta la fecha, en la literatura sobre la persuasión, los intentos explícitos de evitar sesgos causados por aspectos contextuales tales como las características de la fuente se han centrado en los propios procesos correctivos (e.g., Chien \& Hsiao, 2015; Kang \& Herr, 2006; Petty, Wegener, \& White, 1998). Es decir, cuando el receptor del mensaje se percata de un posible sesgo como el acuerdo con una fuente atractiva (e.g., Chaiken, 1979), este trata de eliminar el sesgo ajustando sus pensamientos $\mathrm{u}$ otras respuestas al mensaje en función de la 
dirección y la magnitud percibidas del sesgo causado por la fuente (véase Chien, Wegener, Petty, \& Hsiao, 2014; Wegener \& Petty, 1997). En general, las investigaciones previas han demostrado que estos procesos de corrección suelen ocurrir cuando el pensamiento presenta un nivel de elaboración relativamente alto (e.g., Chien \& Hsiao, 2015; Johar \& Simmons, 2000). Esto es debido a que, para calibrar sus juicios de valor, las personas requieren la motivación y la habilidad suficientes para pensar sobre sus propios procesos mentales (Wegener \& Petty, 1997; Wilson \& Brekke, 1994).

Parece posible que, en ocasiones, los efectos irónicos se deban a los intentos de corregir un sesgo. Como Strack y Mussweiler sugieren (2001; véase también Wegener et al., 2012), el acceso a teorías ingenuas sobre el sesgo y la consideración de los ajustes necesarios puede inducir involuntariamente priming de la variable causante del sesgo o el propio concepto. Si esto ocurre, podrían fomentarse los consiguiente efectos irónicos de incremento del sesgo debido a su mayor accesibilidad (cfr. Macrae, Bodenhausen, Milne, \& Jetten, 1994) ${ }^{4}$. De ser así, es posible que al tener en cuenta un sesgo cuando se trata de evitarlo podría aumentarse la accesibilidad al factor causante del sesgo más allá del marco en el que se activaron las metas de corrección (por el contrario, si se alcanza la meta de corrección del sesgo en el marco inicial de la persuasión, dicha meta de corrección suele ser efímera y confinada mayoritariamente a ese marco inicial; cfr. Förster, Liberman, \& Friedman, 2007). Por otro lado, si la persona cree que el objetivo de evitar el sesgo sigue siendo relevante más allá del marco persuasivo inicial, la accesibilidad de dicho objetivo de corrección podría persistir, causando continuas reducciones del sesgo (o incluso una sobre corrección) en lugar de incrementar irónicamente la influencia del sesgo.

Sin embargo, en ocasiones, ser consciente de un posible sesgo también puede motivar distintos enfoques para su reducción, como el intento de suprimir aquellos pensamientos que reflejen el sesgo (es decir, mantener los 'pensamientos sesgados' alejados de la conciencia). Las consecuencias de la supresión inicial sobre los pensamientos posteriores han sido ampliamente estudiadas en campos distintos de la persuasión. La supresión suele asociarse a un efecto irónico retardado mediante el cual, los pensamientos no deseados 'rebotan' y ejercen un mayor impacto en un marco posterior (Wegner, Schneider, Carter, \& White, 1987; para una revisión del tema, véase Wenzlaff \& Wegner, 2000; para un meta análisis, véase Abramowitz, Tolin, \& Street, 2001). Por ejemplo, después de la supresión eficaz de un estereotipo, los perceptores sociales muestran más respuestas consistentes que incluyen el estereotipo frente a una meta respecto a la que podrían aplicarse reacciones estereotípicas (Macrae et al., 1994). Este impacto posterior del constructo suprimido suele atribuirse a su hiper accesibilidad (a consecuencia de los procesos de control que subyacen tras la supresión; Wegner, 1994; para evidencias electrofisiológicas, véase Giuliano \& Wicha, 2010) cuando ya no hay motivación (Macrae et al., 1994) o recursos cognitivos (Wyer, Sherman, \& Stroessner, 2000) para seguir suprimiendo (cfr. Förster \& Liberman, 2004; Gordijn, Hindriks, Koomen, Dijksterhuis, \& van Knippenberg, 2004). Cuando las personas tratan de controlar el sesgo en 
contextos persuasivos secuenciales, podrían darse efectos rebote similares. En concreto, suprimir una variable (como el atractivo de la fuente) en una situación persuasiva podría incrementar el impacto de esa variable en una situación persuasiva posterior no relacionada.

Los datos sobre este fenómeno son escasos. Tal vez por eso apenas se han discutido los posibles efectos irónicos en la persuasión (para una excepción, véase Wegener et al., 2012). En este artículo, además de discutir esta interesante posibilidad, describimos uno de los pocos estudios (Silva, 2012) que tratan de comparar las estrategias de corrección y de supresión como control del sesgo para comparar directamente sus consecuencias (véase Yzerbyt, Corneille, Dumont, \& Hahn, 2001, para una comparación relacionada sobre inferencias predisposicionales en la formación de impresiones). El presente estudio fue el primero en comparar las estrategias de supresión y de corrección para el control de sesgos en la persuasión. Es decir, el estudio analizó los efectos retardados de los intentos de control de sesgos presentando a los participantes dos mensajes persuasivos aparentemente no relacionados (sobre temas distintos, con fuentes distintas y presentados por investigadores distintos). Todos los mensajes iban acompañados de una fuente atractiva o no atractiva. Algunos participantes recibieron instrucciones para controlar posibles sesgos (que fomentaban la supresión o la corrección) antes de recibir el primer mensaje persuasivo, mientras que otros no. En el caso de los participantes que recibieron instrucciones de control de sesgos, para fomentar la activación efectiva y el uso de estrategias de control, no se les privó de recursos motivacionales o cognitivos (cfr. Wyer, 2007; Wyer et al., 2000).

En el segundo mensaje persuasivo no se les dieron instrucciones para el control del sesgo. No obstante, se manipuló la carga cognitiva durante su recepción. Se hizo así por dos motivos: en primer lugar, como Wyer et al. (2000) demostraron en la supresión del estereotipo, la carga cognitiva mejora la probabilidad de que se apliquen contenidos mentales accesibles en el segundo mensaje aunque los participantes estén motivados para evitar el sesgo. En segundo lugar, la carga cognitiva durante el segundo mensaje presenta condiciones favorables para detectar el impacto de posibles aspectos periféricos tales como el atractivo de la fuente sobre las actitudes (de manera similar a situaciones con un único mensaje, véase Chaiken, Liberman, \& Eagly, 1989; Petty \& Cacioppo, 1986).

La idea es que el control de las influencias percibidas de una característica de la fuente durante el primer mensaje puede incrementar su prominencia o accesibilidad (en comparación con el grupo de control) cuando se encuentra un segundo mensaje. Si es así, los efectos irónicos de los intentos de controlar el sesgo serían evidentes en los efectos del atractivo de la fuente, mayores tras los intentos de supresión o de corrección que en la condición de control. Este patrón podría observarse como una interacción Instrucción x Fuente si aparece en los distintos niveles de carga cognitiva soportada durante el segundo mensaje $\mathrm{o}$ como una interacción Instrucción x Fuente x Carga, si los efectos irónicos ocurren en mayor medida bajo una carga cognitiva alta durante el segundo mensaje. 
Además, el diseño experimental también permitía la detección de efectos irónicos inmediatos (es decir, en la situación persuasiva inicial), que también se han identificado en la investigación sobre la supresión (véase Wenzlaff \& Wegner, 2000; y también discusiones posteriores en Silva, 2012). Estos efectos podrían constituir una consecuencia irónica de los procesos de control de sesgos que todavía no se han tenido en cuenta en la literatura sobre la persuasión. A continuación resumimos los métodos y datos de este experimento.

\section{Método}

\section{Participantes y diseño}

La muestra estaba formada por 136 estudiantes de grado (110 mujeres) que fueron asignados aleatoriamente a un diseño intersujeto de 3 (instrucción: supresión vs. corrección vs. control) x 2 (fuente: atractiva vs. no atractiva) x 2 (carga cognitiva durante el segundo mensaje: baja vs. alta).

\section{Procedimiento}

Los participantes completaron dos pruebas preliminares (cada una supuestamente gestionada por un estudiante distinto) en las que se presentaba, en la pantalla de un ordenador, dos situaciones persuasivas aparentemente no relacionadas. La 'Prueba 1' fue presentada como un estudio de publicidad. Todos los participantes vieron un borrador de un anuncio sobre un dispositivo de almacenamiento USB caracterizado por la imagen del producto, su nombre, y el mensaje: 'Con NewTek3000 puedo almacenar y transmitir datos con regularidad. Es una solución práctica, rápida y segura'. El borrador también incluía indicaciones sobre el lugar en el que aparecerían cuatro detalles o características del producto en la 'versión final'. Sin embargo, dichas características no se especificaban en la versión de evaluación sino que se representaban mediante etiquetas como 'Característica W'. Se informó a todos los participantes de que se estaban realizando unas pruebas preliminares de algunos aspectos antes de decidir sobre el formato final del anuncio y que deberían centrarse en el mensaje que se les presentaba. De especial relevancia, el anuncio incluía una fotografía de un joven que con anterioridad se había comprobado que resultaba relativamente atractivo o no atractivo 5 .

Las condiciones de corrección y de supresión se sumaban a estas instrucciones generales. Tanto las condiciones de corrección como las de supresión ponían de relieve lo siguiente: 'Uno de los aspectos que todavía no hemos decidido es la fotografía que se mostrará en el anuncio. No obstante, hemos decidido poner una en el lugar correspondiente para transmitir el sentido general de cómo será el anuncio definitivo'. En la condición de supresión se pidió a los participantes que 'ignorasen a la persona que presentaba el anuncio y se "olvidasen de ella" al evaluar el mensaje'. 
Después, utilizando una escala de nueve puntos (de 1 a 9, como el resto de las puntuaciones), todos los participantes completaron sus evaluaciones sobre el producto (muy malo/muy bueno, completamente inútil/muy útil, nada interesante/muy interesante), su predisposición a comprar el producto (en absoluto/ por supuesto) y sus evaluaciones del mensaje (muy mal/muy bien, nada efectivo/ muy efectivo). Las respuestas estaban muy correlacionadas $(\alpha$ de Cronbach $=.846$ ), por lo que se calculó la media para crear una medida compuesta de las evaluaciones de esta primera fase (en adelante denominada actitudes posteriores al mensaje 1).

A continuación, se les agradeció su participación y se les indicó que pulsasen una tecla para iniciar el estudio siguiente. Durante ocho segundos aparecía una pantalla de carga, seguida de una pantalla de bienvenida en la que se introducía la 'Prueba 2' sobre psicología ambiental, en un formato totalmente distinto. Se estaba elaborando un panfleto a favor de los sistemas municipales de bicicletas para distribuirlo junto a una petición de firmas. Se informó a los participantes de que, para simular las condiciones en las que el público leería el panfleto, tenían que memorizar un número y reproducirlo correctamente al final del ejercicio. En pantalla apareció un número de dos dígitos (carga baja) o de siete dígitos (carga alta) durante 10 segundos. El panfleto incluía una comunicación personal atribuida a un joven que aparecía en pantalla y cuya apariencia física se había comprobado como relativamente atractiva o no atractiva. Aunque las imágenes atractivas o no atractivas asociadas con el segundo mensaje eran distintas de las asociadas al primero, los niveles de atractivo eran equiparables. Con el segundo mensaje no se ofrecieron instrucciones para controlar el sesgo (prueba 2). El contenido de la comunicación era el siguiente: 'Viví en Holanda durante 2 años y siempre me desplazaba en bicicleta. Además de ser un medio de transporte que no contamina, es una manera fantástica de hacer ejercicio. Uno de los problemas principales que tengo aquí es dónde dejarla. Si los ayuntamientos ofreciesen bicicletas municipales y un sitio para tomarlas y dejarlas, sería mucho más fácil'.

Las actitudes hacia la cuestión (totalmente de acuerdo/totalmente en desacuerdo; nada interesante/muy interesante) y hacia el mensaje (nada eficaz/muy eficaz; nada convincente/muy convincente; nada adecuado/muy adecuado; nada persuasivo/muy persuasivo; muy mal/muy bien; nada motivador/muy motivador que los demás firmen peticiones y nada motivador/muy motivador firmar peticiones nosotros mismos) se valoraron mediante una escala de nueve puntos. Las repuestas estaban muy correlacionadas y se utilizó una medida compuesta por la media $(\alpha=.914)$ denominada actitud posterior al mensaje 2 . A continuación, los participantes indicaron el número que habían memorizado y, también mediante escalas de nueve puntos, valoraron su motivación general sobre la tarea (no me gusta/me gusta y nada interesante/muy interesante; $r=.83$ ), y el atractivo de la fuente en relación con las dos fotografías que habían visto (muy feo/muy guapo; muy poco atractivo/muy atractivo; valoración del atractivo de la fuente para la Prueba 1: $r=.89$; Prueba 2: $r=.90$ ). 


\section{Resultados}

Los análisis preliminares de las actitudes posteriores al mensaje 1 permitieron identificar tres valores atípicos que fueron excluidos de los análisis posteriores. Los análisis preliminares de las actitudes posteriores al mensaje 2 permitieron identificar cinco valores atípicos que también fueron excluidos de los análisis posteriores, junto con dos participantes que no completaron correctamente el ejercicio de carga cognitiva (véase más abajo) ${ }^{6}$. Asimismo, al final de las dos tareas, todos los participantes reportaron una motivación relativamente alta $(M=7.37, D T=1.35)$. Estas respuestas sugieren la predisposición de los participantes a prestar atención a las actividades del estudio (así como, tal vez, un nivel relativamente alto de elaboración respecto al tema).

\section{Comprobación de las manipulaciones}

Tal como se había previsto, los niveles de atractivo percibido respecto a los dos mensajes eran distintos. Un ANOVA 3 (Instrucción) x 2 (Atractivo de la Fuente) x 2 (Carga) reveló que en la Prueba 1 (primer mensaje) la fuente atractiva $(M=4.88)$ se consideró más atractiva que la no atractiva $(M=2.69), F(1,124)=71.50, p<.001$, $\mathrm{\eta}^{2}=.366$. No se observó ningún otro efecto (todos $\left.F \mathrm{~s}<1\right)$. También en la Prueba 2 (segundo mensaje), la fuente atractiva fue considerada más atractiva $(M=4.85)$ que la no atractiva $(M=2.39), F(1,124)=127.90, p<.001 \mathrm{\eta}^{2}=.508$. Este fuerte impacto de la Fuente en las valoraciones del atractivo estaba influenciado por la Instrucción [Instrucción x Fuente, $F(2,124)=5.39, p=.006, \mathrm{y}^{2}=.080$ ] y por la Carga [Fuente $\mathrm{x}$ Carga, $\left.F(1,124)=6.82, p=.010, \mathrm{y}^{2}=.052\right]$. Los participantes de la condición de corrección valoraron la fuente de modo más similar en todos los niveles de manipulación del atractivo $\left(M_{\text {atractiva }}=4.03 ; M_{\text {no atractiva }}=2.59\right)$, en comparación con los participantes en la condición de supresión $\left(M_{\text {atractiva }}=5.29 ; M_{\text {no atractiva }}=2.28\right)$ o en la condición de control $\left(M_{\text {atractiva }}=5.23 ; M_{\text {no atractiva }}=2.29\right)$. No obstante, cabe destacar que, al comparar directamente la fuente atractiva y la no atractiva en la condición de corrección, las puntuaciones revelaron un efecto relativamente fuerte y significativo de la manipulación $t(124)=3.72, p<.001 ; d=0.67$.

Asimismo, aunque los participantes con alta carga cognitiva evaluaron las fuentes de manera más homogénea $\left(M_{\text {atractiva }}=4.54 ; M_{\text {no atractiva }}=2.65\right)$ que los participantes con baja carga cognitiva $\left(M_{\text {atractiva }}=5.16 ; M_{\text {no atractiva }}=2.13\right)$, las comparaciones entre la fuente atractiva y la no atractiva reveló un efecto de la manipulación incluso en la condición de carga elevada, $t(124)=6.15, p<.001$; $d=1.10$. La interacción triple entre el nivel de instrucción, el atractivo de la fuente y la carga cognitiva no era significativa $(F<1)$.

\section{Prueba 1: El mensaje persuasivo inicial}

En el primer mensaje persuasivo, la supresión podía eliminar cualquier efecto de la fuente o, si no resultaba eficaz, podía fomentar o incrementar un efecto en la actitud de los participantes. Como en investigaciones anteriores, las instrucciones dirigidas a la corrección de sesgos deberían reducir el impacto del atractivo de la 
fuente, bien disminuyendo los efectos de su atractivo o bien invirtiendo los efectos de su atractivo debido a una sobre corrección (véase Kang \& Herr, 2006; Petty et al., 1998).

El ANOVA Instrucción x Fuente (factores manipulados antes de medir las actitudes posteriores al mensaje 1) reveló solo una interacción significativa, $F(2$, $127)=4.18, p=.017, \mathrm{n}^{2}=.062$, lo que sugiere la posible eficacia de las instrucciones de corrección y efectos paradójicos de supresión. Para conocer mejor esta interacción, llevamos a cabo comparaciones planeadas de las actitudes posteriores al mensaje 1 en todas las condiciones en función de la fuente y para todos los tipos de instrucción. Las actitudes posteriores al mensaje 1 eran más favorables para la fuente atractiva $(M=5.91)$ que para la no atractiva $(M=4.87)$ solo en la condición de supresión, $t(127)=2.71, p=.008, d=0.48$. No se observaron efectos significativos del atractivo de la fuente en la condición de control $\left(M_{\text {atractiva }}=5.60 ; M_{\text {no atractiva }}=6.14\right)$ ni en la condición de corrección $\left(M_{\text {atractiva }}=5.83 ; M_{\text {no atractiva }}=5.76\right), t \mathrm{~s}<1.36$.

\section{Prueba 2: Segundo mensaje persuasivo}

Todos los participantes de la condición de baja carga reportaron el número correcto, lo que sugiere que los participantes respondieron a la manipulación de carga cognitiva. Dos participantes de la condición de carga alta, que recordaron menos de la mitad de los siete dígitos correctamente, fueron excluidos de los análisis posteriores (véase Gilbert \& Hixon, 1991).

Analizamos las actitudes posteriores al mensaje 2 mediante un ANOVA 3 (instrucción) x 2 (fuente) x 2 (carga cognitiva). Este análisis reveló una interacción marginal Instrucción x Fuente, $F(2,117)=2.72, p=.070, \mathrm{y}^{2}=.045$, que reflejaba los efectos observados tras el primer mensaje persuasivo, al menos en algunos aspectos. Las comparaciones entre las dos condiciones en función de la fuente revelaron que aunque el atractivo no ejercía un impacto significativo en la condición de control $\left(M_{\text {atractiva }}=6.57 ; M_{\text {no atractiva }}=6.63 ; t<1\right)$, se observó su efecto 'irónico' en la condición de supresión $\left(M_{\text {atractiva }}=6.53 ; M_{\text {no atractiva }}=5.79 ; t(117)=2.01 p=.047\right.$; $d=0.37$ ). Tampoco se observó un efecto significativo del atractivo de la fuente en la condición de corrección $\left(M_{\text {atractiva }}=5.77 ; M_{\text {no atractiva }}=6.29 ; t(117)=1.26, p=.211\right.$; $d=0.23)$. De hecho, como mucho podría haber cierta acumulación de las metas correctivas en tanto que la fuente no atractiva produjo reacciones más favorables al mensaje que la fuente atractiva aunque de manera no significative (véase Tabla 1).

El triple efecto ómnibus entre Instrucciones, Fuente y Carga no llegaba a ser significativo $F(2,117)=2.161, p=.120, \mathrm{n}^{2}=.036$. Sin embargo, cuando centramos el análisis únicamente en la comparación entre las condiciones de supresión y de control, un ANOVA 2 (Instrucciones) x 2 (Fuente) x 2 (Carga) reveló un posible efecto irónico de la supresión del atractivo de la fuente moderado por la carga - Instrucción $\times$ Fuente $\times$ Interacción de la carga, $F(1,117)=4.28$, $p=.041, \mathrm{y}^{2}=.041$. En el caso de los participantes que se encontraban con una carga alta en el segundo mensaje, la interacción Instrucción x Fuente reveló que los efectos del atractivo de la fuente eran significativamente mayores cuando los 
Tabla 1. Mensaje 2 - valoración media de las actitudes (desviación típica entre paréntesis).

Carga cognitiva

\begin{tabular}{cc}
\hline Baja & Alta \\
\hline Fuente & Fuente
\end{tabular}

\begin{tabular}{lcccc}
\hline Instrucciones & Atractiva & No atractiva & Atractiva & No atractiva \\
\hline Control & $6.93(0.81)$ & $6.49(0.99)$ & $6.21(1.10)$ & $6.77(0.61)$ \\
Corrección & $6.19(1.75)$ & $6.69(1.40)$ & $5.36(1.41)$ & $5.89(0.71)$ \\
Supresión & $6.23(1.70)$ & $6.10(1.41)$ & $6.82(0.70)$ & $5.48(1.51)$ \\
\hline
\end{tabular}

participantes tenían que suprimir el atractivo de la fuente durante el primer mensaje $\left(M_{\text {atractiva }}=6.82 ; M_{\text {no atractiva }}=5.48\right)$ que cuando no tenían que suprimirlo (condición de control; $\left.M_{\text {atractiva }}=6.21 ; M_{\text {no atractiva }}=6.77\right), t(117)=2.59, p=.011$, $d=0.49$. Además, la diferencia entre una fuente atractiva y una no atractiva en el segundo mensaje era significativa cuando los participantes tenían instrucciones de supresión en el primer mensaje, $t(117)=2.61, p=.010, d=0.48$, pero no cuando no recibían ninguna instrucción de suprimir posibles sesgos en ese primer mensaje (condición de control), $t(117)=1.06, p=.291 . d=0.195$. No obstante, cuando los participantes tenían una carga cognitiva baja durante el segundo mensaje, la tendencia era distinta. Es decir, la actitud no se veía afectada por el atractivo de la fuente del segundo mensaje ni cuando en el primer mensaje tenían que suprimir el efecto de la fuente $\left(M_{\text {atractiva }}=6.23 ; M_{\text {no atractiva }}=6.10 ; t<1\right)$ ni en las condiciones de control $\left(M_{\text {atractiva }}=6.93 ; M_{\text {no atractiva }}=6.49 ; t<1\right), F<1$ para Instrucción $\times$ Fuente.

Por lo que respecta a la comparación del impacto del atractivo de la fuente en el segundo mensaje, cuando los participantes tenían que corregir su efecto en el primer mensaje (en comparación con la condición de control), en general no se observaron diferencias significativas entre las condiciones de corrección y las de control, $(F<1)$, ni esta relación se veía afectada por la carga (interacción triple: $F<1$; véase Figura 1).

\section{Algunas consideraciones sobre la potencia estadística}

En este apartado ampliamos las consideraciones realizadas por Silva (2012) sobre la potencia de los análisis realizados. El estudio se llevó a cabo en un tiempo en que la literatura no prestaba mucha atención a la potencia estadística, pero obviamente, con un único estudio, las conclusiones deberían ser interpretadas teniendo en cuenta que publicaciones de baja potencia estadística surgidas de un único estudio puedan incluir una proporción más elevada de errores de Tipo 1 (Pashler \& Harris, 2012). Especialmente, dada la naturaleza en cierto grado especulativa de cualquier comparación entre los potenciales efectos irónicos de la supresión frente a la corrección. A medida que se llevan a cabo pruebas 


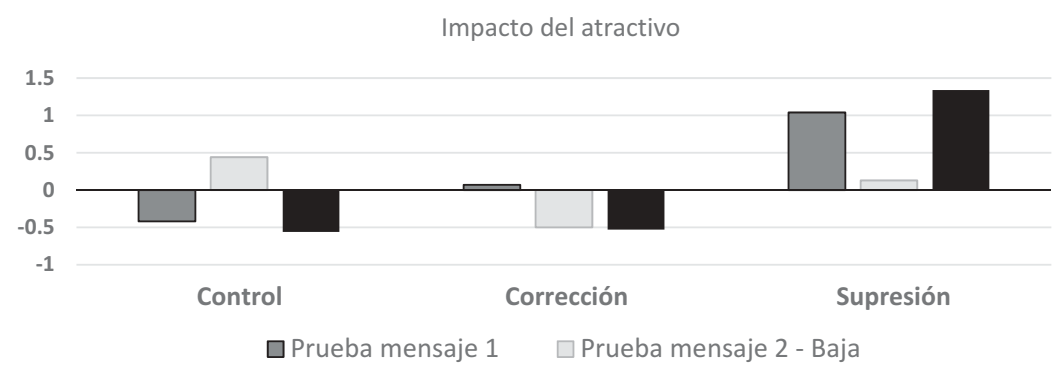

Figura 1. Impacto diferencial del atractivo de la fuente (atractiva - no atractiva) por condición experimental.

adicionales de posibles efectos irónicos, el nivel de potencia de cualquier estudio individual tendría menor relevancia para identificar dichos efectos que la potencia de un conjunto de datos más exhaustivo (para una discusión sobre el tema, véase Fabrigar \& Wegener, 2016; McShane \& Böckenholt, 2017). Como un primer estudio sobre este tema, tal vez podríamos utilizar los efectos relevantes (como la triple interacción observada entre Instrucción, Fuente y Carga, al comparar solo las condiciones de supresión y de control) como una estimación del tamaño del efecto para futuros estudios $\left(f^{2}=0.193\right)$. Si adoptásemos ese enfoque, se necesitaría aproximadamente 262 participantes para alcanzar una potencia de $80 \%$ en cualquier réplica del estudio. No obstante, es perfectamente posible que cualquier estimación obtenida a partir de este estudio represente una sobre estimación del efecto en la población. De ser así, los esfuerzos por analizar efectos irónicos similares podrían requerir un número considerablemente mayor de participantes que lo estimado sobre la base de los resultados obtenidos en este estudio.

\section{Discusión}

Este estudio (parte de la tesis de Silva, 2012) se centraba en las consecuencias de las estrategias de control de sesgos activadas en una situación persuasiva sobre un mensaje posterior. Por lo que sabemos, se trata del primer estudio que se centra directamente en el posible efecto rebote en la persuasión. Como estudio preliminar (y dadas las restricciones de potencia), cualquier conclusión debe ser interpretada con cautela, aunque algunas partes del estudio sugieren que los efectos irónicos de la supresión son posibles en contextos de persuasión. En particular, el estudio sugiere que los esfuerzos iniciales de suprimir pensamientos coherentes con las características de la fuente podrían incrementar irónicamente los efectos de la fuente en un mensaje posterior, en comparación con una condición de control en la que no se suprimían pensamientos iniciales relacionados con la fuente. A pesar de la naturaleza preliminar de los datos actuales, consideramos de utilidad presentar el estudio con la esperanza de que pueda fomentar nuevos esfuerzos por analizar los efectos irónicos de las estrategias de control de sesgos en la persuasión. 


\section{Limitaciones y explicaciones}

En este estudio, los efectos irónicos de la supresión del atractivo de la fuente ocurrieron especialmente cuando los participantes disponían de pocos recursos cognitivos al recibir el segundo mensaje (es decir, en condiciones de una carga cognitiva elevada). Los niveles elevados de carga cognitiva durante el segundo mensaje podrían facilitar el incremento de los efectos de la accesibilidad del atractivo de la fuente. Y, sin embargo, en cierto modo, no deja de ser curioso que los efectos de la fuente en el segundo mensaje deberían haber sido más probables en condiciones de carga alta que de carga baja, incluso en el grupo de control (pero no fue así). Es posible que hubiese una falta de atención general al atractivo de la fuente que se incrementó cuando las instrucciones de supresión en el primer mensaje hicieron las características de la fuente más accesibles.

Por lo que respecta a los intentos de corrección de sesgos (es decir, el ajuste por las influencias percibidas), este estudio no reveló efectos irónicos retardados (véase también Yzerbyt et al., 2001). No obstante, sigue valiendo la pena explorar esa posibilidad en futuras investigaciones. Por ejemplo, en nuestro estudio se analizó la supresión y la corrección en un contexto de un nivel informativo relativamente bajo (con poca información para elaborar un juicio). Sin embargo, en otras condiciones de mayor riqueza informativa, algunos ejemplos más amplios e intensos de corrección podrían producir efectos de rebote debido a la consideración repetitiva del factor de sesgo o debido al agotamiento de los recursos de autocontrol. Por el contrario, en el caso de la supresión, contextos más ricos en información podrían facilitar mayor diversidad de contenidos mentales de distracción (no relacionados con el contexto siguiente), facilitando así el alejamiento de contenidos no deseados (e.g., el atractivo de la fuente) de la consciencia, lo que reduciría posibles efectos irónicos posteriores (véase Silva, 2012; Wegener et al., 2012, para otras discusiones adicionales, incluido el papel de aspectos como el momento de presentación de las instrucciones de control de sesgos).

Cualquier efecto irónico de la supresión en este estudio no ocurriría simplemente por atraer la atención sobre el atractivo de la fuente y sus efectos sesgantes porque las instrucciones de corrección no tuvieron los mismos efectos. Más bien la clave podría estar en los intentos de 'apartar de la mente' las características de la fuente (posiblemente relacionado con la falta de conciencia individual del pensamiento repetido sobre la fuente del mensaje; cfr. Baird, Smallwood, Fishman, Mrazek, \& Schooler, 2013). Los mecanismos típicos activados por la supresión incluyen una mayor accesibilidad (Wegner, 1994), agotamiento del autocontrol (Gailliot et al., 2007), o inferencias motivacionales (Förster \& Liberman, 2004). No obstante, otra explicación posible es que los efectos irónicos de la supresión surjan de una inducción de priming procedimental por la que la atención al tema del pensamiento suprimido sigue emergiendo en situaciones posteriores (cfr. Shen \& Wyer, 2008). Algún tipo de inducción procedimental también podría ser relevante para explicar por qué la corrección del sesgo en un primer mensaje resultaría en una tendencia a corregir también en 
un mensaje posterior. Es decir, los participantes de las condiciones de corrección y supresión podrían seguir aplicando (o tratando de aplicar) las mismas estrategias al enfrentarse al segundo mensaje persuasivo. No obstante, en este estudio tenemos que señalar una limitación tanto en la supresión como en la corrección y es que se ha obtenido escasa evidencia que demuestre que los participantes suprimían o corregían posibles sesgos durante el primer mensaje, mucho menos para identificar los mecanismos activados durante la supresión o la corrección. Las diferencias de resultados en las distintas condiciones de instrucción sugieren que los participantes actuaban de manera distinta en cada condición, pero no podemos garantizar que cumpliesen estrictamente los procesos pretendidos o qué posibles mecanismos entraban en funcionamiento.

En conclusión, de acuerdo con Tormala y Clarkson $(2007,2008)$ y Chien y Hsiao (2015), destacaríamos que la necesidad de que los estudios sobre la persuasión abarquen más allá del contexto de mensaje persuasivo único que ha dominado la literatura relevante (véase también Cialdini \& Guadagno, 2004; Sleeth-Keppler \& Wheeler, 2011). Aunque reconocemos la posibilidad de efectos irónicos inmediatos, nuestro interés principal aquí son los efectos en sentido descendente que los intentos de controlar posibles sesgos pueden ejercer sobre el modo en que las personas gestionan un mensaje posterior sin ninguna relación conceptual con el primero.

Esta dinámica de ampliación temporal de la perspectiva es particularmente importante si tenemos en cuenta que las personas suelen enfrentarse a una sucesión de mensajes persuasivos sobre distintos temas (con frecuencia presentados por diversas fuentes). En algunos de estos contextos, el contenido recibido antes del mensaje persuasivo podría dar pie a tratar de controlar posibles sesgos (como cuando el atractivo se considera motivo de éxito inmerecido de un comunicador que se presenta antes del mensaje persuasivo, e.g., Kang \& Herr, 2006; o cuando un mensaje anterior exhorta al receptor a ignorar a los patrocinadores célebres de otras marcas, como en el anuncio de Sprite 'Obey Your Thirst' (Hazle caso a tu sed); Chien \& Hsiao, 2015). El campo de la persuasión en general, y el de los contextos dinámicos de mensajes múltiples en particular, también ofrecen un marco perfecto para analizar las diferencias entre diversas estrategias de control de sesgos (como la corrección y la supresión). Estas diferencias apenas han sido exploradas y sigue habiendo muchas preguntas interesantes (y posibles consecuencias significativas) por responder.

\section{Notas}

1. Anteriormente, los efectos de rebote se asociaban empíricamente con los intentos de suprimir ciertos tipos pensamientos específicos en lugar de relacionarse con intentos de evitar un sesgo particular. El análisis de los efectos irónicos (de rebote) de la corrección requiere un diseño experimental específico que no se ha utilizado previamente en investigaciones centradas en los procesos correctivos. Por ejemplo, en un contexto de persuasión, detectar un efecto rebote de la corrección del atractivo de una fuente (e.g., Petty et al., 1998) requeriría una situación persuasiva posterior en la que la variable (atractivo de la fuente) puede tener un efecto detectable. Los 
estudios sobre los mensajes secuenciales son escasos y no existen estudios previos diseñados para analizar los efectos rebote de la corrección de sesgos.

2. Tanto los rostros atractivos como los no atractivos de las Pruebas 1 y 2 procedían de las imágenes utilizadas en Minear y Park (2004) y en Tottenham et al. (2009). Sin embargo, para las versiones atractivas combinamos diversas imágenes para crear rostros finales con mayor nivel de atractivo.

3. Estos valores atípicos se identificaron mediante diagramas de caja (boxplot) en SPSS (1.5IQR) independientemente para cada celda del diseño. Cabe destacar que estos análisis eliminaron valores atípicos distintos de las respuestas del primer y del segundo mensaje persuasivo. La interdependencia de ambas fases podría aconsejar la eliminación completa de todos los participantes atípicos de todos los análisis. Dicha estrategia no modifica el patrón de los resultados.

\section{Acknowledgements / Agradecimientos}

The writing of this article was supported by the Portuguese National Science Foundation (FCT), both by a $\mathrm{PhD}$ grant SFRH/BD/28102/2006 and a research grant UID/PSI/04810/ 2013. I La elaboración de este artículo ha recibido el apoyo de la Fundación para la Ciencia y la Tecnología de Portugal (FCT) a través del programa de doctorado SFRH/ BD/28102/2006 y del programa de investigación UID/PSI/04810/2013.

\section{Disclosure statement}

No potential conflict of interest was reported by the authors. / Los autores no han referido ningún potencial conflicto de interés en relación con este artículo.

\section{ORCID}

Teresa Garcia-Marques (iD http://orcid.org/0000-0002-6233-0799

Duane T. Wegener (D) http://orcid.org/0000-0001-7639-4251

\section{References / Referencias}

Abramowitz, J. S., Tolin, D. F., \& Street, G. P. (2001). Paradoxical effects of thought suppression: A meta-analysis of controlled studies. Clinical Psychology Review, 21, 683-703.

Albarracín, D., Johnson, B., \& Zanna, M. (2005). The handbook of attitudes. Mahwah, NJ: Erlbaum.

Baird, B., Smallwood, J., Fishman, D. J., Mrazek, M. D., \& Schooler, J. W. (2013). Unnoticed intrusions: Dissociations of meta-consciousness in thought suppression. Consciousness and Cognition, 22, 1003-1012. doi:10.1016/j.concog.2013.06.009

Burkley, E. (2008). The role of self-control in resistance to persuasion. Personality and Social Psychology Bulletin, 34, 419-431. doi:10.1177/0146167207310458

Chaiken, S. (1979). Communicator physical attractiveness and persuasion. Journal of Personality and Social Psychology, 37, 1387-1397. doi:10.1037/0022-3514.37.8.1387

Chaiken, S., Liberman, A., \& Eagly, A. (1989). Heuristic and systematic processing within and beyond the persuasion context. In J. S. Uleman \& J. A. Bargh (Eds.), Unintended thought (pp. 212-252). New York, NY: Guilford Press.

Chien, Y.-W., \& Hsiao, C.-C. (2015). Be yourself, image is nothing: Bias correction when viewing ads in sequence. Social Influence, 10, 19-30. doi:10.1080/ 15534510.2014 .890667 
Chien, Y.-W., Wegener, D. T., Hsiao, C.-C., \& Petty, R. E. (2010). Dimensional range overlap and context effects in consumer judgments. Journal of Consumer Research, 37, 530-542. doi:10.1086/652415

Chien, Y.-W., Wegener, D. T., Petty, R. E., \& Hsiao, C.-C. (2014). The flexible correction model: Bias correction guided by näive theories of bias. Social and Personality Psychology Compass, 8/6, 275-286. doi:10.1111/spc3.12105

Cialdini, R. B., \& Guadagno, R. E. (2004). Sequential request compliance tactics. In R. H. Gass \& J. S. Steiter (Eds.), Perspectives on persuasion, compliance-gaining, and social influence (pp. 207-222). Boston, MA: Allyn \& Bacon.

Fabrigar, L. R., \& Wegener, D. T. (2016). Conceptualizing and evaluating the replication of research results. Journal of Experimental Social Psychology, 66, 68-80. doi:10.1016/j.jesp.2015.07.009

Förster, J., \& Liberman, N. (2004). A motivational model of post-suppressional rebound. European Review of Social Psychology, 15, 1-32. doi:10.1080/10463280340000081

Förster, J., Liberman, N., \& Friedman, R. S. (2007). Seven principles of goal activation: A systematic approach to distinguishing goal priming from priming of non-goal constructs. Personality and Social Psychology Review, 11, 211-233. doi:10.1177/ 1088868307303029

Gailliot, M., Baumeister, R., DeWall, C., Maner, J., Plant, E., Tice, D., ... Schmeichel, B. (2007). Self-control relies on glucose as a limited energy source: Willpower is more than a metaphor. Journal of Personality and Social Psychology, 92, 325-336. doi:10.1037/0022-3514.92.2.325

Gilbert, D., \& Hixon, J. (1991). The trouble of thinking: Activation and application of stereotypic beliefs. Journal of Personality and Social Psychology, 60, 509-517. doi:10.1037/0022-3514.60.4.509

Giuliano, R. J., \& Wicha, N. Y. (2010). Why the white bear is still there: Electrophysiological evidence for ironic semantic activation during thought suppression. Brain Research, 1316, 62-74. doi:10.1016/j.brainres.2009.12.041

Gordijn, E., Hindriks, I., Koomen, W., Dijksterhuis, A., \& Van Knippenberg, A. (2004). Consequences of stereotype suppression and internal suppression motivation: A self-regulation approach. Personality and Social Psychology Bulletin, 30, 212-224. doi: $10.1177 / 0146167203259935$

Johar, G. V., \& Simmons, C. J. (2000). The use of concurrent disclosures to correct invalid inferences. Journal of Consumer Research, 26, 307-322. doi:10.1086/ jcr.2000.26.issue-4

Kang, Y., \& Herr, P. (2006). Beauty and the beholder: Toward an integrative model of communication source effects. Journal of Consumer Research, 33, 123-130. doi:10.1086/jcr.2006.33.issue-1

Macrae, C. N., Bodenhausen, G., Milne, A., \& Jetten, J. (1994). Out of mind but back in sight: Stereotypes on the rebound. Journal of Personality and Social Psychology, 67, 808-817. doi:10.1037/0022-3514.67.5.808

McShane, B. B., \& Böckenholt, U. (2017). Single-paper meta-analysis: Benefits for study summary, theory testing, and replicability. Journal of Consumer Research, 43, 1048-1063.

Minear, M., \& Park, D. C. (2004). A lifespan database of adult facial stimuli. Behaviour Research Methods, Instruments, \& Computers, 36, 630-633. doi:10.3758/BF03206543

Pashler, H., \& Harris, C. R. (2012). Is the replicability crisis overblown? Three arguments examined. Perspectives on Psychological Science, 7, 531-536. doi:10.1177/ 1745691612463401

Petty, R. E., \& Cacioppo, J. T. (1986). The elaboration likelihood model of persuasion. In L. Berkowitz (Ed.), Advances in experimental social psychology (Vol. 19, pp. 123-205). New York, NY: Academic Press. 
Petty, R. E., \& Wegener, D. T. (1998). Attitude change: Multiple roles for persuasion variables. In D. Gilbert, S. Fiske, \& G. Lindzey (Eds.), The handbook of social psychology (4th ed., pp. 323-390). New York, NY: McGraw-Hill.

Petty, R. E., Wegener, D. T., \& White, P. (1998). Flexible correction processes in social judgment: Implications for persuasion. Social Cognition, 16, 93-113. doi:10.1521/ soco.1998.16.1.93

Shen, H., \& Wyer, R. S. (2008). Procedural priming and consumer judgments: Effects on the impact of positively and negatively valenced information. Journal of Consumer Research, 34, 727-737. doi:10.1086/523292

Silva, P. P. (2012). Controlo de impactos indesejados em contexto persuasivo: Correcção, supressão e seus efeitos irónicos (Unpublished doctoral dissertation). ISPA, Lisbon, Portugal.

Sleeth-Keppler, D., \& Wheeler, S. C. (2011). A multi-dimensional association approach to sequential consumer judgments. Journal of Consumer Psychology, 21, 14-23. doi:10.1016/j.jcps.2010.09.007

Strack, F., \& Mussweiler, T. (2001). Resisting influence: Judgmental correction and its goals. In J. P. Forgas \& K. Williams (Eds.), Social influence: Direct and indirect processes. The Sydney symposium of social psychology (pp. 199-212). New York, NY: Psychology Press.

Tormala, Z. L., \& Clarkson, J. J. (2007). Assimilation and contrast in persuasion: The effects of source credibility in multiple message situations. Personality and Social Psychology Bulletin, 33, 559-571. doi:10.1177/0146167206296955

Tormala, Z. L., \& Clarkson, J. J. (2008). Source trustworthiness and information processing in multiple message situations: A contextual analysis. Social Cognition, 26, 357-367. doi:10.1521/soco.2008.26.3.357

Tottenham, N., Tanaka, J. W., Leon, A. C., McCarry, T., Nurse, M., Hare, T. A., \& Nelson, C. (2009). The NimStim set of facial expressions: Judgments from untrained research participants. Psychiatry Research, 168, 242-249. doi:10.1016/j. psychres.2008.05.006

Wegener, D. T., \& Petty, R. E. (1997). The flexible correction model: The role of naïve theories in bias correction. In M. P. Zanna (Ed.), Advances in experimental social psychology (Vol. 29, pp. 141-208). San Diego, CA: Academic Press.

Wegener, D. T., Petty, R. E., Smoak, N. D., \& Fabrigar, L. R. (2004). Multiple routes to resisting attitude change. In E. S. Knowles \& J. A. Linn (Eds.), Resistance and persuasion (pp. 13-38). Mahwah, NJ: Erlbaum.

Wegener, D. T., Silva, P. P., Petty, R. E., \& Garcia-Marques, T. (2012). The metacognition of bias regulation. In P. Briñol \& K. DeMarree (Eds.), Social metacognition (pp. 81-99). New York, NY: Psychology Press.

Wegner, D. M. (1994). Ironic processes of mental control. Psychological Review, 101, 34-52.

Wegner, D. M., Schneider, D., Carter, S., \& White, L. (1987). Paradoxical effects of thought suppression. Journal of Personality and Social Psychology, 53, 5-13.

Wenzlaff, R., \& Wegner, D. M. (2000). Thought suppression. Annual Review of Psychology, 51, 59-91. doi:10.1146/annurev.psych.51.1.59

Wheeler, S. C., Briñol, P., \& Hermann, A. (2007). Resistance to persuasion as self-regulation: Ego-depletion and its effects on attitude change processes. Journal of Experimental Social Psychology, 43, 150-156. doi:10.1016/j.jesp.2006.01.001

Wilson, T. D., \& Brekke, N. (1994). Mental contamination and mental correction: Unwanted influences on judgments and evaluations. Psychological Bulletin, 116, 117-142. doi:10.1037/0033-2909.116.1.117

Wyer, N. (2007). Motivational influences on compliance with and consequences of instructions to suppress stereotypes. Journal of Experimental Social Psychology, 43, 417-424. doi:10.1016/j.jesp.2006.03.001 
Wyer, N., Sherman, J., \& Stroessner, S. (2000). The roles of motivation and ability in controlling the consequences of stereotype suppression. Personality and Social Psychology Bulletin, 26, 13-25. doi:10.1177/0146167200261002

Yzerbyt, V., Corneille, O., Dumont, M., \& Hahn, K. (2001). The dispositional inference strikes back: Situational focus and dispositional suppression in causal attribution. Journal of Personality and Social Psychology, 81, 365-376. 